\title{
Using a Dielectric Capacitance Cell to Determine the Dielectric Properties of Pure Sand Artificially Contaminated with $\mathrm{Pb}, \mathrm{Cd}, \mathrm{Fe}$, and $\mathrm{Zn}$
}

\author{
Mohammed Dahim (D), ${ }^{1}$ Musab Abuaddous $(\mathbb{D}),{ }^{2}$ Rabah Ismail $\left(\mathbb{D},{ }^{3}\right.$ Hashem Al-Mattarneh $\left(\mathbb{D},{ }^{2}\right.$ \\ and Aiman Jaradat ${ }^{2}{ }^{2}$
}

${ }^{1}$ Faculty of Engineering, King Khaled University, Abha, Saudi Arabia

${ }^{2}$ Civil Engineering Department, Yarmoulk University, Irbid, Jordan

${ }^{3}$ Civil Engineering Department, Jadara University, Irbid, Jordan

Correspondence should be addressed to Hashem Al-Mattarneh; drhashem2010@yahoo.com

Received 3 August 2020; Revised 27 November 2020; Accepted 1 December 2020; Published 14 December 2020

Academic Editor: Fedor Lisetskii

Copyright (c) 2020 Mohammed Dahim et al. This is an open access article distributed under the Creative Commons Attribution License, which permits unrestricted use, distribution, and reproduction in any medium, provided the original work is properly cited.

\begin{abstract}
This paper presents a new method of dielectric capacitance cell as a proposed device for measuring the impedance of pure sand artificially contaminated with four heavy metals. Dielectric constant and loss factor of clean and contaminated sand at various levels were calculated from the measured sand impedances. The advantages and benefits of using the proposed dielectric capacitance cell were its low cost, simple calculation, calibration procedures, portable and lightweight, and easy to modify the electrodes to suit testing in the field. Pure sand was saturated with water artificially polluted in the lab with $\mathrm{Pb}, \mathrm{Cd}, \mathrm{Fe}$, and $\mathrm{Zn}$ at heavy metal contents $0,7.5,15,22.5$, and $30 \mathrm{mg} / \mathrm{kg}$ of sand. The dielectric properties of polluted sand were evaluated at a frequency range from $100 \mathrm{kHz}$ to $1000 \mathrm{kHz}$. The polluted sand exhibit different dielectric constants and loss factors from the unpolluted sand. The results also indicate that the dielectric constant decreases with increasing pollution level for all heavy metals. This may attribute to the polarization mechanism change with existing heavy metal. The loss factor of sand increases with the increasing pollution level. This may be explained by the increase of ionic conductivity of pore water with heavy metal in the sand. Sand polluted with heavy metal with higher resistivity and density possess a higher dielectric constant and lower loss factor than other polluted metals. Evaluation of the dielectric characteristics of polluted sand could have the potential to monitor heavy metal pollution. Even with promising results obtained with the proposed dielectric device, it is necessary to explore several other factors affecting the measurements such as sand water content, soil texture, and type of soil. Also, testing polluted soil near industrial pollution is needed.
\end{abstract}

\section{Introduction}

The soil could be contaminated by heavy metals due to industrial and human activities such oil industry, solid waste disposal, leachate of sanitary landfill, and heavy oil reservoir problems. Soil contaminated by heavy metals is considered a vital and dangerous problem in many countries around the world. In recent years, with the development of the global economy, both the type and content of heavy metals in the soil caused by human activities have gradually increased, resulting in the deterioration of the environment [1-3].
Heavy metals are highly hazardous to the environment and organisms. It can be affected by soil productivity and food security through the food chain, whereas the metals in the soil can be taken up by plants and transferred to a higher trophic level by means of herbivory [4-7]. The persistence of heavy metals in soils is a long process and becomes a critical global issue [7-9].

High concentrations of heavy metals in soils may cause long-term risks to ecosystems and humans $[10,11]$. Although heavy metals are released in varying quantities into the soil from parent materials, increasing environmental 
contamination has been caused by human activities, such as fossil fuel combustion, waste disposal sewage irrigation, wars, mining and smelting activities, and the use of pesticides and fertilizers [12-15].

Measured complex permittivity and dielectric properties of materials have been used extensively in the last two decades. Several geophysical electromagnetic methods could be used to determine dielectric properties of materials such as soil. These methods include the free-space microwave sensor [16, 17], microwave waveguide method [18], time domain reflectometer [19-21], and parallel plate capacitor $[22,23]$.

Recently, several researchers investigated the use of dielectric methods for evaluation and assessment of soil and rock contaminated with heavy metals. Liu et al. [24] studied the dielectric constant of chrome-contaminated soil. The result from this study indicates that the real and imaginary parts of the complex dielectric constant increase with an increase in contamination concentration and water content. Dielectric dispersion characteristics of sand contaminated by heavy metal and landfill leachate were evaluated by lee et al. [25]. The results show that the imaginary part of soil contaminated with $\mathrm{Pb}$ significantly increased with the concentration of the contaminants in both unsaturated and saturated sand in the frequency $75 \mathrm{kHz}$ up to $10 \mathrm{MHz}$. Chenaf and Amara [26] valuated the dielectric properties of unsaturated soil contaminated with heavy metal and diesel using TDR. The measured dielectric properties have been found to increase when heavy metal concentration increases. Saltas et al. [27] conducted a study on measuring dielectric and conductivity of sandstone samples in frequency from $10 \mathrm{~Hz}$ to $1000 \mathrm{kHz}$ to investigate if dielectric spectroscopy could detect pollution that leach in porous rock and soil. The results of this investigation indicate that the relaxation time of pure sandstone is strongly influenced by small changes in leachate concentration, but it is insensitive at higher concentrations. Saltas et al. [28] also investigated the use of dielectric and conductivity of bentonite contaminated with $\mathrm{Ni}$ and $\mathrm{Pb}$. The results of dielectric proved to be sensitive at low concentrations of heavy metals and could be used to estimate the level of the heavy metals in bentonite samples. In addition, the electrode capacitor method is used widely for soil evaluation, and recently, several studies were conducted in environmental assessment and soil pollution [29-31].

Heavy metal is an element with metallic properties. Most of heavy metals have an atomic number greater than 20 . Standard permissible limits of heavy metals in soil vary from country to country and within the same country for different areas such as residential or industrial area. The standard maximum limits vary with several factors such as $\mathrm{pH}$ and temperature. Table 1 presents the comparison of the most common contaminants of heavy metal in several countries and the maximum limits proposed by U.S. EPA and Europe [32-34].

In this paper, an electromagnetic method was manufactured and used for determination of soil dielectric properties. This method operates in low frequency, which makes it simple for calculation and reduced the cost of low frequency source of electromagnetic signal. This proposed method is portable, light weight, and low cost. The proposed method is called dielectric capacitive method. This was used to investigate whether the dielectric properties of sand calculated from the measured sand impedances could be used to detect heavy metal pollution in sand and estimate the pollution level.

\section{Materials and Methods}

A new device called dielectric capacitance cell (DCC) is proposed to measure the impedance of pure sand artificially polluted in lab with four heavy metals at various levels. The dielectric constant and loss factor of clean and polluted sand were calculated from the measured impedances of sand in the frequency range of $100 \mathrm{kHz}-1000 \mathrm{kHz}$. The DCC device, pure sand characteristics, heavy metal properties, the testing procedures, and testing regime are presented in the following subsections.

2.1. Dielectric Capacitance Cell. When materials such as soil exposed to alternative current (AC), an interaction between soil material and AC will be controlled by a physical soil property called complex permittivity $\varepsilon^{*}$. The complex permittivity of the soil consists of two distinguished properties, namely, the real part called dielectric constant $\varepsilon^{\prime}$ which explains how much energy from AC signal absorbed by the soil, and the imaginary part called the loss factor $\varepsilon^{\prime \prime}$ represents the amount of energy lost from AC signal to conduct the electric current through the soil. Complex permittivity of soil is given by

$$
\varepsilon^{*}=\varepsilon^{\prime}+j \varepsilon^{\prime \prime} .
$$

Several techniques and sensor technologies were used to determine the real and imaginary component of complex permittivity of soil. These methods include the free-space microwave sensor, time domain method, resonant cavity, waveguide method, and electrode method [16-22]. Among these methods, the parallel electrode capacitance method is used due to the low cost manufacture, simple calculation method, and easy to calculate the complex permittivity from the measured impedance of the soil under the test, portable, and electrode could be fabricated to suite the testing in the field [29-31]. Therefore, this dielectric capacitive method was used in this study.

The capacitive cell measures the complex impedance $Z_{\text {sand }}=Z^{\prime}+j Z^{\prime \prime}$ of the sand under testing. The complex permittivity of soil was calculated from the measured complex admittance of sand $Y_{\text {sand }}=Y^{\prime}+j Y^{\prime \prime}$ which is related to the complex impedance of the soil using equation (2). Equations (3)-(5) were used to calculate sand complex permittivity known as the dielectric constant and loss factor. Further details of this calculation could be found in literature $[22,35]$.

$$
\begin{gathered}
Y=\frac{1}{Z}, \\
\text { Dielectric constant }=\varepsilon_{\text {sand }}^{\prime}=\frac{Y_{\text {sand }}^{\prime}}{\omega C_{o}},
\end{gathered}
$$


TABLe 1: The basic properties of the four heavy metals [32, 33, 34].

\begin{tabular}{|c|c|c|c|c|c|c|c|c|}
\hline \multirow{2}{*}{ Country/Organization } & \multicolumn{8}{|c|}{ Residential area } \\
\hline & As & $\mathrm{Cd}$ & $\mathrm{Cr}$ & $\mathrm{Cu}$ & $\mathrm{Hg}$ & $\mathrm{Ni}$ & $\mathrm{Pb}$ & $\mathrm{Zn}$ \\
\hline Max. limits on heavy metals applied to soils (USEPA, 2000) & 75 & 85 & 1500 & 4300 & 57 & 420 & 840 & 7500 \\
\hline European Union standards & 60 & $1-3$ & $100-180$ & $50-140$ & 50 & $30-75$ & $50-300$ & $150-300$ \\
\hline Australia & 20 & 3 & 50 & 100 & 1 & 60 & 300 & 200 \\
\hline Canada & 20 & 3 & 250 & 150 & 0.8 & 100 & 100 & 200 \\
\hline Germany & 50 & 5 & 500 & 200 & 5 & 200 & 1000 & 600 \\
\hline UK & 43 & 1.8 & - & - & 26 & 230 & - & 200 \\
\hline USA & 0.11 & 20 & 11 & 270 & 1 & 210 & 150 & 1100 \\
\hline
\end{tabular}

$$
\begin{gathered}
\tan (\delta)=\frac{Y_{\text {sand }}^{\prime \prime}}{Y_{\text {sand }}^{\prime}}, \\
\text { Loss factor }=\varepsilon_{\text {sand }}^{\prime \prime}=\varepsilon_{\text {sand }}^{\prime} \tan (\delta) \frac{Y_{\text {sand }}^{\prime \prime}}{\omega C_{o}} .
\end{gathered}
$$

Dielectric characterization of clean and polluted sand samples was performed in the lab using a dielectric capacitance cell (DCC). The prototype lab DCC and its schematic diagram are shown in Figures 1(a) and 1(b), respectively. The internal dimensions of DCC were $80 \times 80 \times 40 \mathrm{~mm}$. Two connected electrodes with dimensions of $80 \times 80 \times 2 \mathrm{~mm}$ were attached to the two opposite faces of the rectangular cell. The two electrodes were connected to the LCR meter. The LCR meters form the source of the AC current signal and measure the impedance of the soil sample under testing. The LCR meter was connected to a personal computer for data acquisition. The personal computer was used to automate the testing and calculate the dielectric constant and loss factor of clean and contaminated sand using equations (1)-(5). Cable impedance, plate impedance, and fringing impedance were determined and removed from the measured impedances of sand using an appropriate model circuit reported in a previous study [22, 35]. This setup operates and measures dielectric properties of sand over frequency range from $100 \mathrm{kHz}$ to $1000 \mathrm{kHz}$. Extension of operation frequency could be made with the same setup up to $30 \mathrm{MHz}$ with good accuracy.

2.2. Clean Sand Samples. In this study, pure clean sand was used. The grain size distribution of the clean pure sand was established by performing sieve analysis according to ASTM Standard D 442 standard. The results of the sieve analysis and particle size distribution of sand are presented in Figure 2 . The properties of clean pure sand such as porosity $(n)$, specific gravity (Gs), and bulk density were measured according to the procedure in reference [36], and the results are listed in Table 2.

2.3. Heavy Metals and Testing Regime. Four heavy metals $(\mathrm{Pb}, \mathrm{Fe}, \mathrm{Cd}$, and $\mathrm{Zn})$ were used in this study to pollute the pure sand samples at five levels of contamination for each heavy metal. Pure sand was saturated with water artificially polluted in the lab with $\mathrm{Pb}, \mathrm{Cd}, \mathrm{Fe}$, and $\mathrm{Zn}$ at heavy metal contents $0,7.5,15,22.5$, and $30 \mathrm{mg} / \mathrm{kg}$ of sand. This pollution level is considered low pollution limit, and it is close to the allowable limit of $\mathrm{Cd}$ adopted in the USA which was the highest allowable limit compared to other countries. The amount of heavy metals in the aqueous solution $\left(\mathrm{NO}_{3}\right)$ was added to water. The mixtures were stirred for 15 minutes at room temperature $\left(25^{\circ} \mathrm{C}\right)$ to have a homogeneous solution. The total amount of water and heavy metals used equals to the amount of reaching saturated condition of sand which is $40 \%$. This procedure will make all clean and polluted samples having the same moisture condition of $40 \%$ equal to the porosity of pure sand and form $100 \%$ saturated sample with water for all levels of pollution and for all four heavy metals used in this study. This procedure was adopted to remove the effect of water to measure dielectric properties of clean and contaminated sand. The variation of the dielectric properties of clean and polluted sand will be affected by heavy metal type and content. The clean and polluted sample at any pollution level was inserted in the dielectric cell, and the impedance of the sample was measured at 10 frequency values. The range of testing frequency was from $100 \mathrm{kHz}$ to $1000 \mathrm{kHz}$ with an increment equal to $100 \mathrm{kHz}$. The dielectric properties of clean and polluted sand were calculated from the measured sand impedances at each frequency.

The basic properties of the four heavy metals $\mathrm{Pb}, \mathrm{Fe}, \mathrm{Cd}$, and $\mathrm{Zn}$ used in this study are given in Table 3 . The properties of these heavy metals are used for understanding of the effect of heavy metal type on dielectric properties based on the certain properties of the heavy metal. $\mathrm{Pb}$ has the highest density and highest electrical resistivity, while $\mathrm{Zn}$ possesses the lowest of both density and electrical resistivity.

\section{Results and Discussion}

The effect of heavy metals $\mathrm{Pb}, \mathrm{Fe}, \mathrm{Cd}$, and $\mathrm{Zn}$ and level of pollution on the complex permittivity in the frequency range from $100 \mathrm{kHz}$ to $1000 \mathrm{kHz}$ were explored. The effect of frequency, heavy metal type, and heavy metal pollution level was evaluated and presented in the following subsections.

3.1. Effect of Frequency and Heavy Metals. In general, dielectric properties of material are affected by several factors including frequency, density, and moisture condition. The results of both the dielectric constant and loss factor calculated from the measured impedances of clean and polluted sand with four heavy metals $(\mathrm{Pb}, \mathrm{Fe}, \mathrm{Cd}$, and $\mathrm{Zn})$ at five levels of pollution using the proposed new device DCC are 


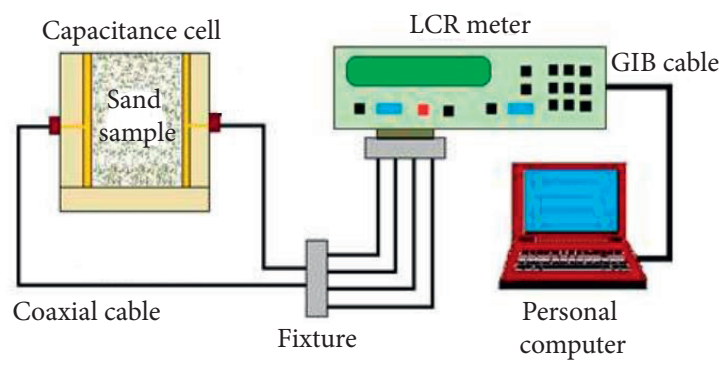

(a)

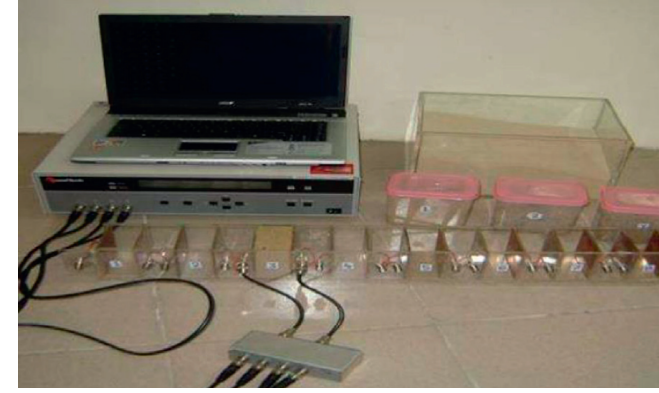

(b)

FIgure 1: Dielectric capacitance cell. (a) Schematic diagram of DCC. (b) Prototype of lab DCC.

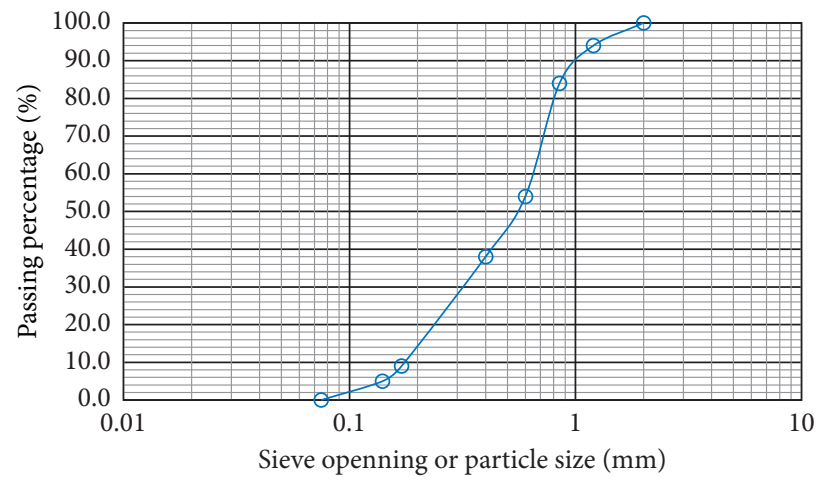

FIGURE 2: Grain size distribution and sieve analysis of the clean pure sand.

TABLE 2: Properties of clean sandy soil.

\begin{tabular}{lc}
\hline Soil properties & $\begin{array}{c}\text { Value of sandy } \\
\text { soil sample }\end{array}$ \\
\hline Total volume $(\mathrm{V})$ of the dry sample $\left(\mathrm{cm}^{3}\right)$ & 315.66 \\
Volume of solid $\left(\mathrm{cm}^{3}\right)$ & 189.39 \\
Volume of voids $(\mathrm{Vv})\left(\mathrm{cm}^{3}\right)$ & 126.26 \\
Porosity $n$ & $0.4(40 \%)$ \\
Specific gravity $\left(G_{\mathrm{s}}\right)$ & 2.64 \\
Bulk density $\left(\mathrm{g} / \mathrm{cm}^{3}\right)$ & 1.584 \\
\hline
\end{tabular}

presented in Figures 3-6. The results in these figures indicate the change of both the dielectric constant and loss factors of all samples with frequency range from $100 \mathrm{kHz}$ to $1000 \mathrm{kHz}$. The results of all samples indicate that as frequency increases, the sand net polarisation drops as each polarisation mechanism ceases to contribute, and hence, its dielectric constant and loss factor drops. The polarization of a dielectric material such as clean and polluted sand used in this study is contributed by ionic, electronic, and dipole polarization. The electronic and dipole polarization of sand samples occurs in longer interval of time than the time required for alternative current $(\mathrm{AC})$ to change its direction at high frequency. The dipole molecules of sand cannot reorient themselves within a short time available at the high frequency. This will not allow the sand material to store more energy from the applied $\mathrm{AC}$ where the $\mathrm{AC}$ direction changed very fast. This phenomenon is responsible to decrease both the dielectric constant and loss factor at high frequency for sand sample at all heavy metal types and content.

The results of the dielectric constant at low frequency increase with increasing heavy metal content for all heavy metals used as shown in Figures 3(a)-6(a). This result may attribute to the high electrode polarization at low frequency and double layer polarization. Similar trend was observed in literature [27]. To avoid the electrode effect in low frequency less than $300 \mathrm{kHz}$, it is recommended to compare the results at frequency higher than $300 \mathrm{kHz}$. After $300 \mathrm{kHz}$, the trend was opposite, and the sand containing higher heavy metal content shows lower dielectric constant.

The results of the loss factor indicate that at all frequency ranges, the loss factor of polluted sand increases with increasing heavy metal content as shown in Figures 3(b)-6(b). This increase in the loss factor of high level of polluted sand is due to increasing ionic concentration. The ion concentration increased because all heavy metals have a good conductivity compared with sand particles. Therefore, electrical conduction is enhanced by the free movement of charges, and the ionic constituents act as charge carriers. These ions are coming from the electrochemical reaction, anodic reaction, where the metal dissolves into aqueous metal ions, and electrons are generated.

3.2. Relationship between Dielectric and Pollution Level. To better visualize the relationship between the level of heavy metals in sand and the dielectric properties, the results of 
TABLE 3: The basic properties of the four heavy metals.

\begin{tabular}{lcccc}
\hline Basic properties & $\mathrm{Pb}$ & $\mathrm{Fe}$ & $\mathrm{Cd}$ & $\mathrm{Zn}$ \\
\hline Density $\left(\mathrm{g} / \mathrm{cm}^{3}\right)$ & 11.34 & 7.874 & 8.65 & 7.14 \\
Atomic number & 82 & 26 & 48 & 30 \\
Electrical resistivity $(\mathrm{n} \Omega \mathrm{m})$ & 208 & 96.1 & 72.7 & 59.0 \\
Standard atomic weight & 207.2 & 55.845 & 112.414 & 65.38 \\
Thermal conductivity $\mathrm{W} /(\mathrm{m} \cdot \mathrm{K})$ & 53.3 & 80.4 & 96.6 & 116 \\
Crystal structure & Face-centered & Body-centered & Hexagonal close-packed & Hexagonal close-packed \\
\hline
\end{tabular}

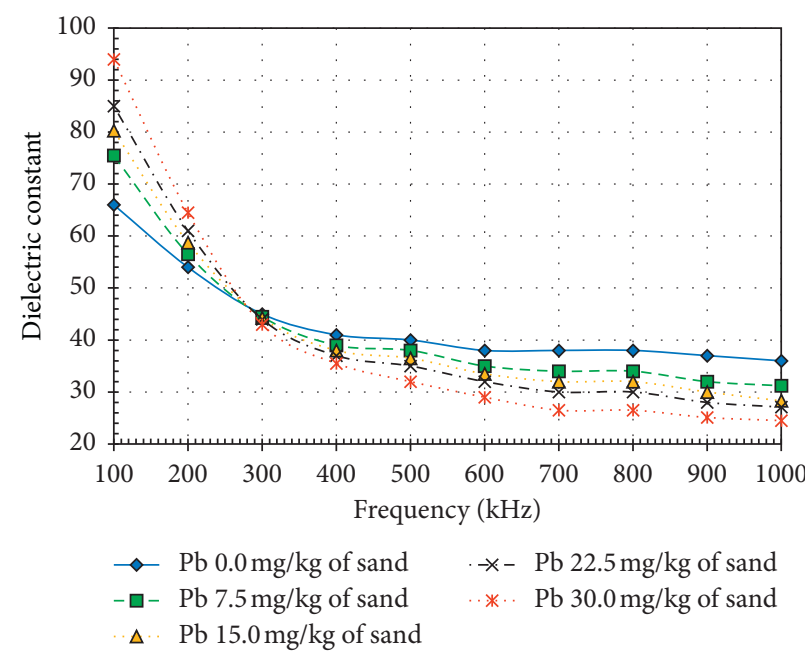

(a)

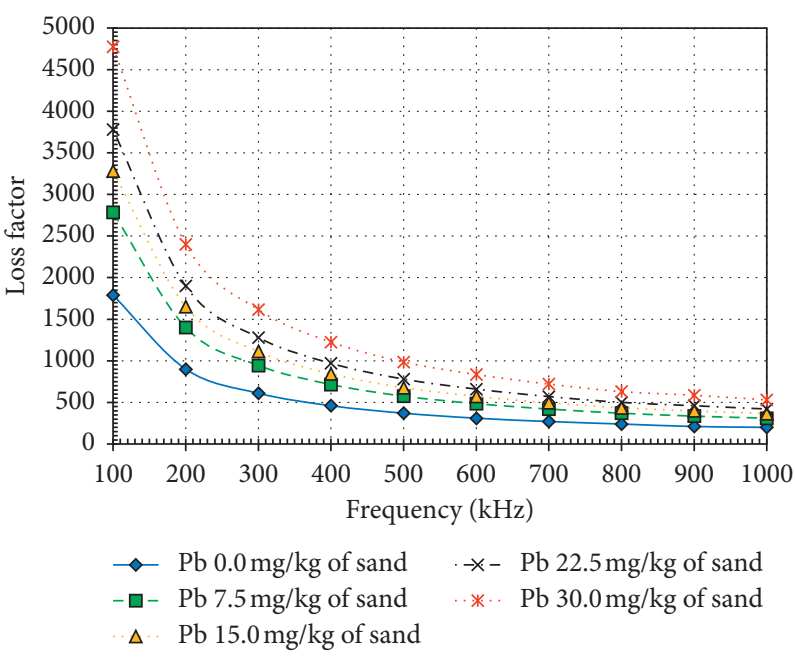

(b)

Figure 3: Complex permittivity of sand contaminated with $\mathrm{Pb}$. (a) Dielectric constant versus frequency. (b) Loss factor versus frequency.

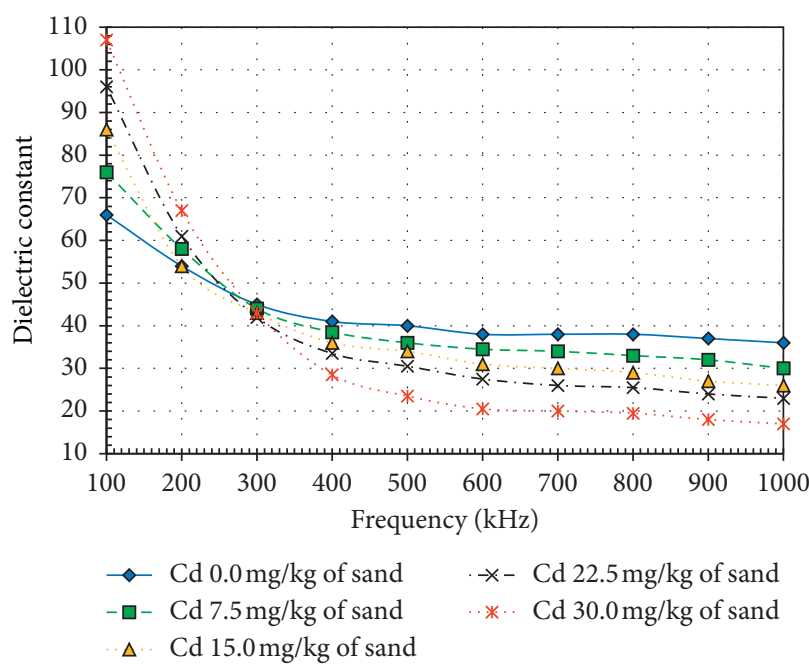

(a)

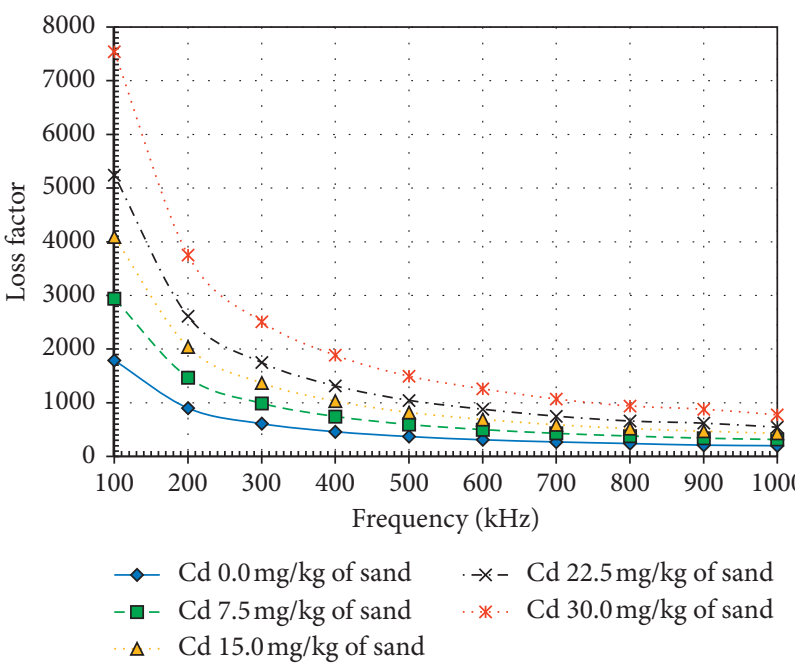

(b)

Figure 4: Complex permittivity of sand contaminated with Cd. (a) Dielectric constant versus frequency. (b) Loss factor versus frequency.

each heavy metal were compared at frequencies $500 \mathrm{kHz}$ and $700 \mathrm{kHz}$. The statistical analysis of the relationship between heavy metal content in sand material and complex permittivity of sand was performed. The linear regression model to relate dielectric properties with the level of pollution is given by

$$
\begin{aligned}
\text { Dielectric constant } & =\varepsilon_{\text {sand }}^{\prime}=c_{o}+c_{1}(\text { pollution level }) \\
\text { Loss factor } & =\varepsilon_{\text {sand }}^{\prime \prime}=b_{o}+b_{1}(\text { pollution level })
\end{aligned}
$$

where $c_{o}, c_{1}, b_{o}$, and $b_{1}$ are the regression model parameter constants. The regression linear models of dielectric 


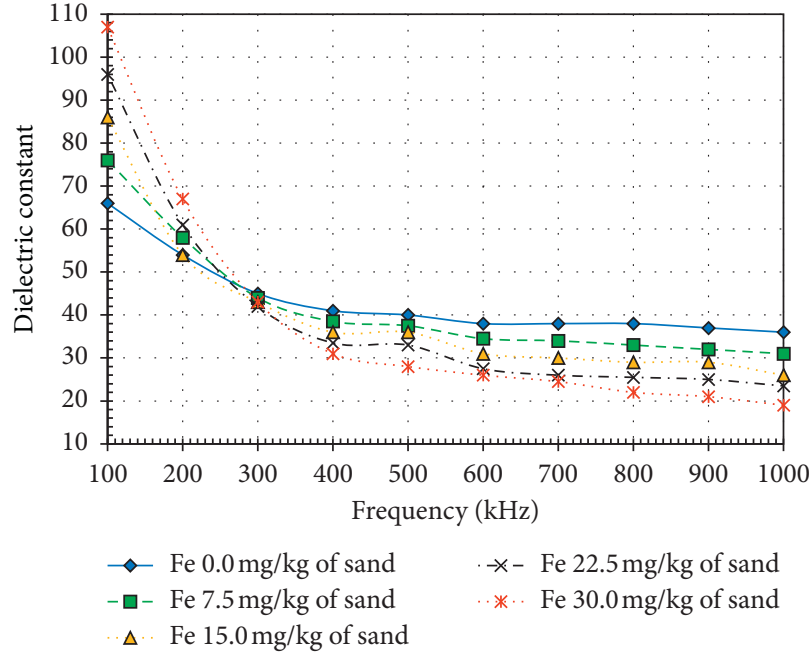

(a)

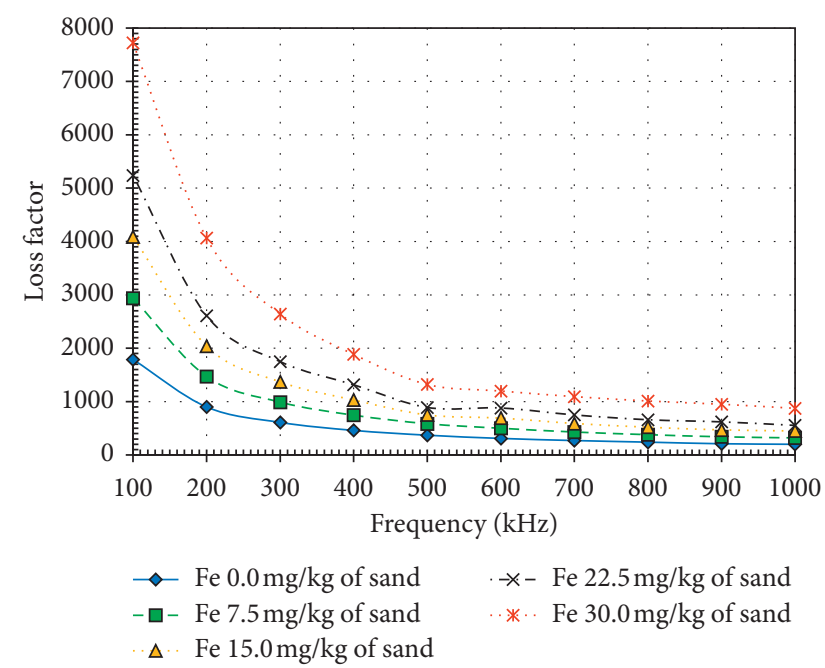

(b)

Figure 5: Complex permittivity of sand contaminated with Fe. (a) Dielectric constant versus frequency. (b) Loss factor versus frequency.

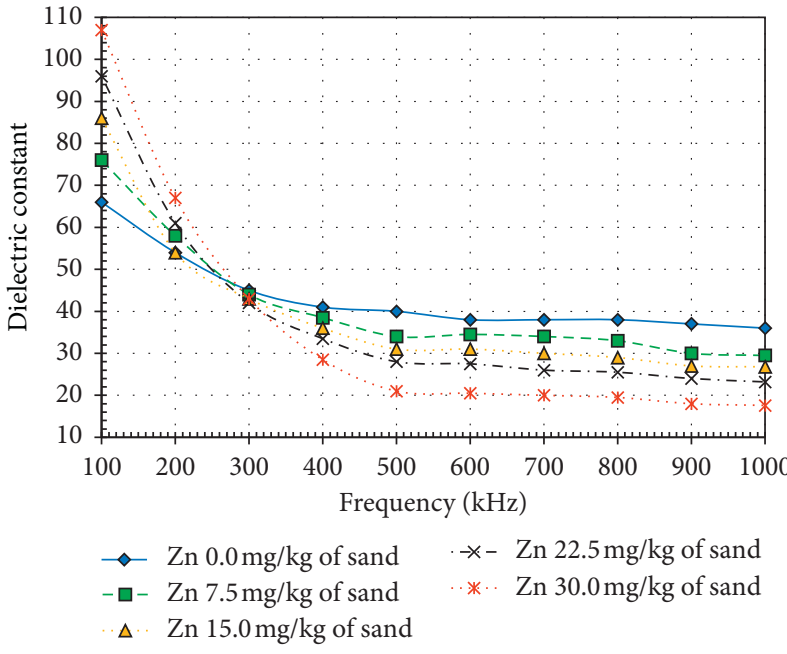

(a)

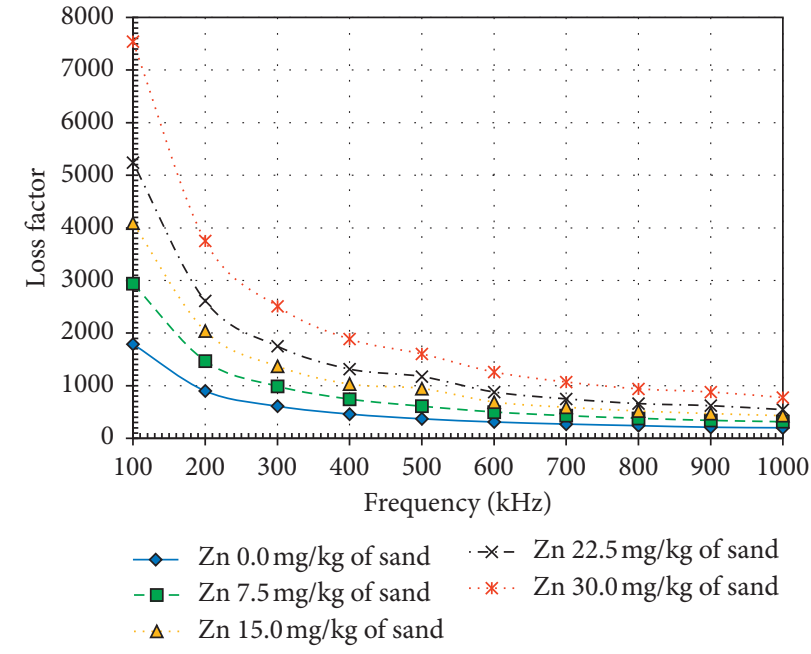

(b)

Figure 6: Complex permittivity of sand contaminated with Zn. (a) Dielectric constant versus frequency. (b) Loss factor versus frequency.

constants with the pollution level at frequencies $500 \mathrm{kHz}$ and $700 \mathrm{kHz}$ for all types of heavy metals are given in Figures $7(\mathrm{a})-10(\mathrm{a})$. The parameters of the regression analysis of these linear relations at two frequencies are indicated in Figures 7(a)-10(a). The models show high quality of fit where the square correlation factors are high and close to one. The relationship indicates that the increasing level of pollution of heavy metals in sand will decrease the dielectric constants of sand. The square correlation coefficients were $0.9810,0.9544,0.9533$, and 0.9738 for heavy metals $\mathrm{Pb}, \mathrm{Cd}$, $\mathrm{Fe}$, and $\mathrm{Zn}$, respectively. This high quality of fit allow the researchers to estimate and quantify the level of heavy metal pollution of pure artificial sand polluted with these heavy metal based on the calculated value of the dielectric constant obtained using the proposed dielectric capacitive cell.
The regression linear models of loss factors with the pollution level at frequencies $500 \mathrm{kHz}$ and $700 \mathrm{kHz}$ for all types of heavy metals are given in Figures $7(\mathrm{~b})-10(\mathrm{~b})$. The parameters of the regression analysis of these linear relations at two frequencies are indicated in Figures 7(b)-10(b). The models show high quality of fit where square correlation factors are high and close to one. The relationship indicates that the increasing level of pollution of heavy metal in sand will increase the loss factor of sand. The square correlation coefficients were $0.9800,0.9730,0.9521$, and 0.9889 for heavy metals $\mathrm{Pb}, \mathrm{Cd}, \mathrm{Fe}$, and $\mathrm{Zn}$, respectively. This high quality of fit allows the researchers to estimate and quantify the level of heavy metal pollution of pure artificial sand polluted with these heavy metals based on the calculated value of loss factors obtained using the proposed dielectric capacitive cell. 


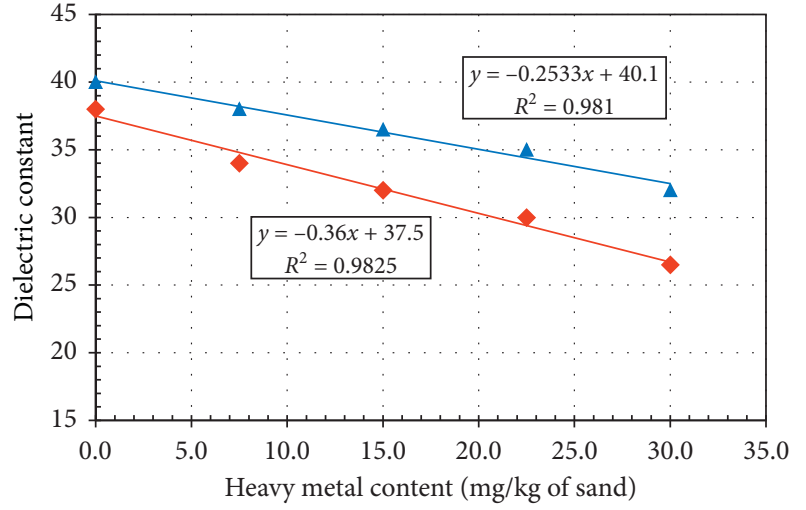

A Frequency $=500 \mathrm{kHz}$

- Frequency $=700 \mathrm{kHz}$

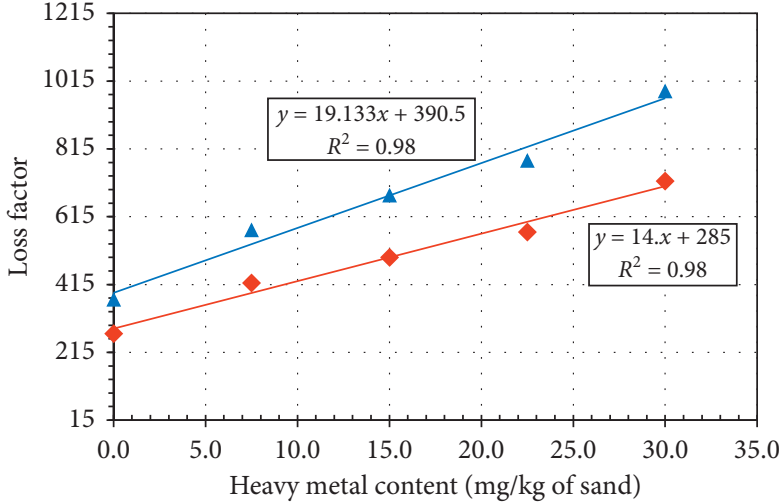

A Frequency $=500 \mathrm{kHz}$

- Frequency $=700 \mathrm{kHz}$

(b)

Figure 7: Regression analysis of complex permittivity and $\mathrm{Pb}$ content. (a) Dielectric constant versus $\mathrm{Pb}$ content. (b) Loss factor versus $\mathrm{Pb}$ content.

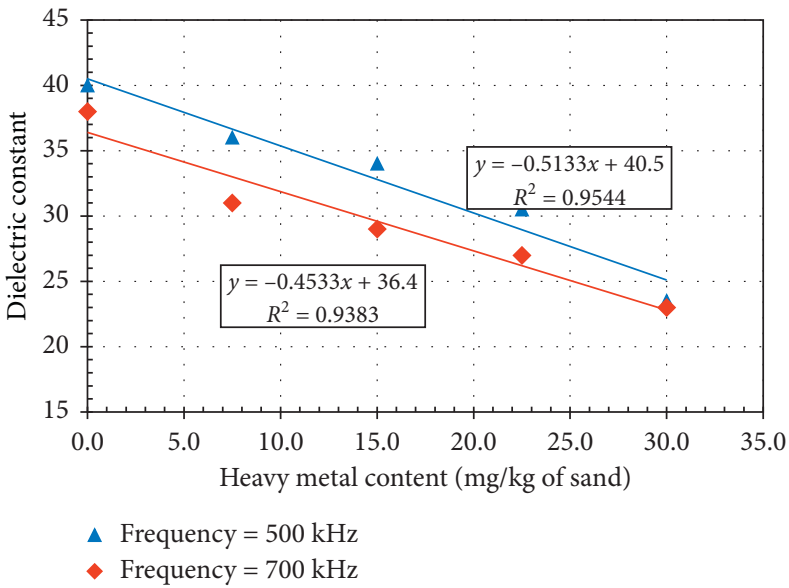

(a)

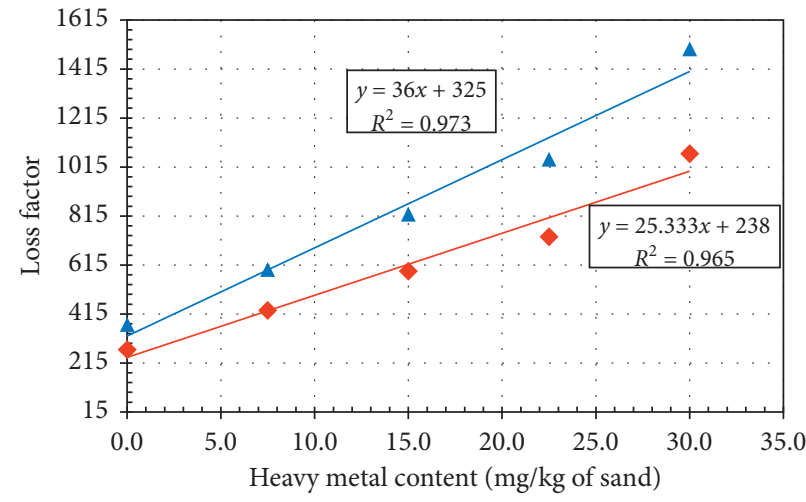

- Frequency $=500 \mathrm{kHz}$

- Frequency $=700 \mathrm{kHz}$

(b)

FIGURE 8: Regression analysis of complex permittivity and Cd content. (a) Dielectric constant versus Cd content. (b) Loss factor versus Cd content.

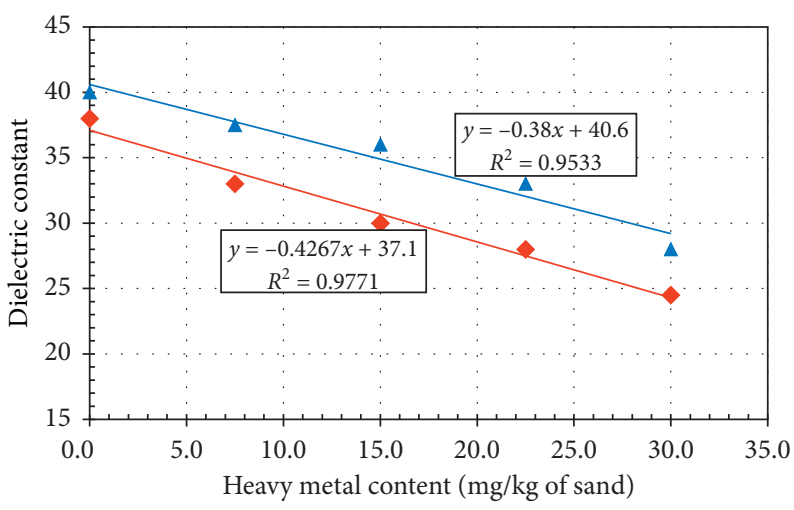

A Frequency $=500 \mathrm{kHz}$

- Frequency $=700 \mathrm{kHz}$

(a)

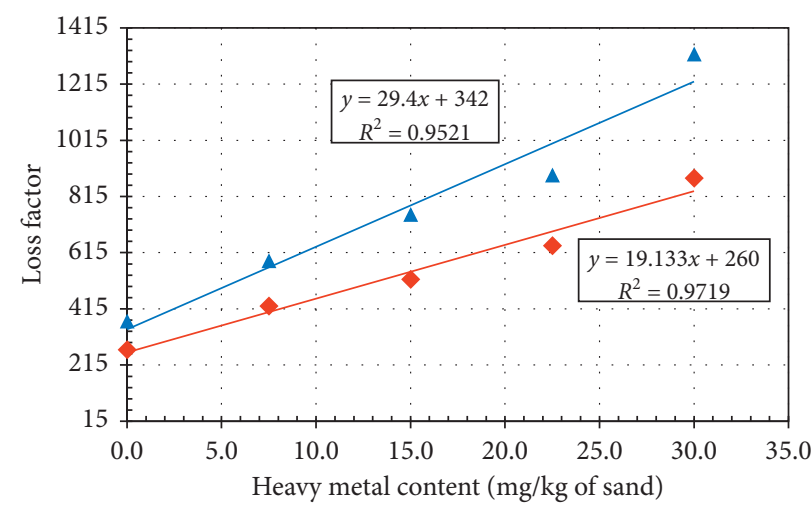

\ Frequency $=500 \mathrm{kHz}$

- Frequency $=700 \mathrm{kHz}$

(b)

FIGURE 9: Regression analysis of complex permittivity and Fe content. (a) Dielectric constant versus Fe content. (b) Loss factor versus Fe content. 


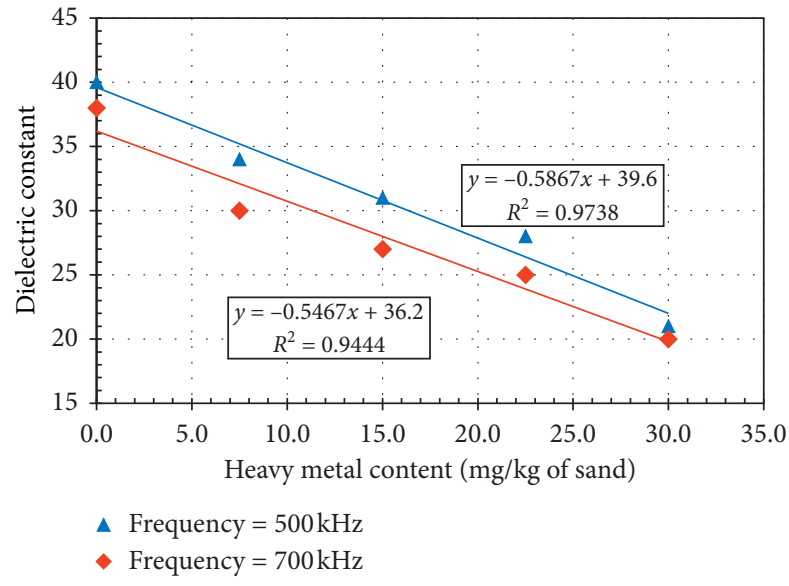

(a)

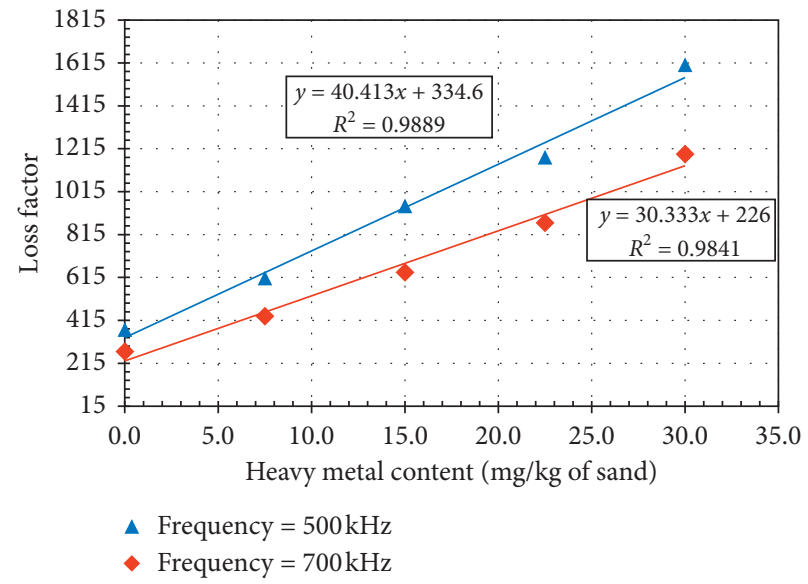

(b)

Figure 10: Regression analysis of complex permittivity and Zn content. (a) Dielectric constant versus Zn content. (b) Loss factor versus Zn content.

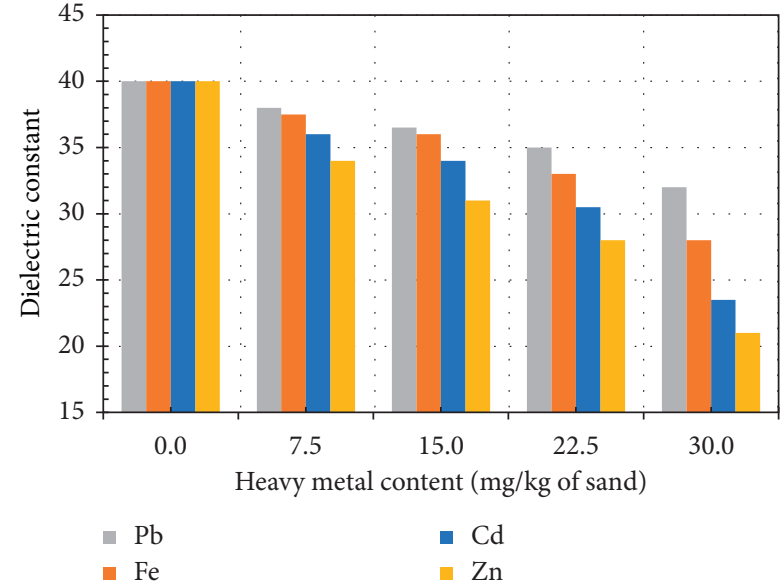

(a)

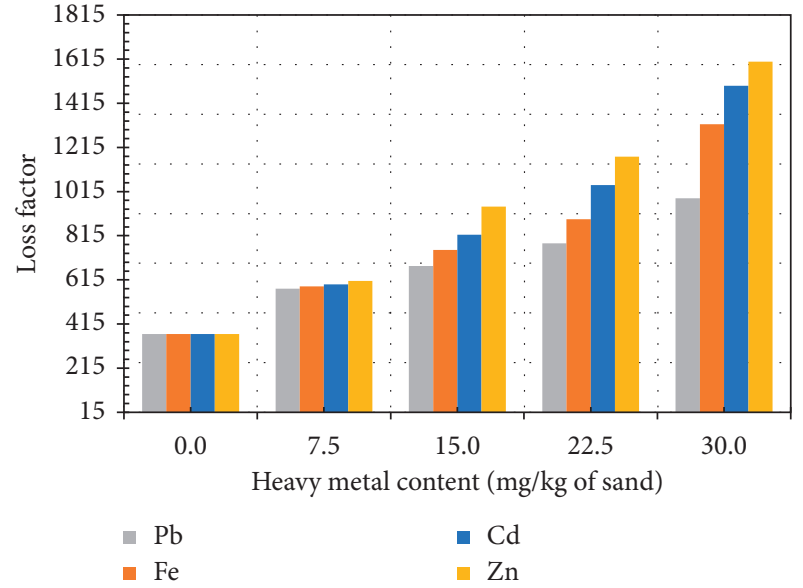

(b)

FIGURE 11: Effect of type and content of heavy metals on soil complex permittivity at frequency $500 \mathrm{kHz}$. (a) Dielectric constant versus heavy metal content. (b) Loss factor versus heavy metal content.

3.3. Effect of Heavy Metal. To compare the signature of heavy metal type and content on dielectric properties of sand, the results of complex permittivity of sand polluted with the four heavy metals were presented at $500 \mathrm{kHz}$. Comparison of the effect of heavy metal type and content on dielectric properties is given in Figure 11. At frequency $500 \mathrm{kHz}$, the dielectric constant of polluted sand decreases with the increasing heavy metal pollution content. This could be attributed to high conducting of heavy metal compared to the sand particles. An increase in the conductive phase of pore structure from increasing heavy metal content reduces the dielectric constant of sand mixture with heavy metal. This trend was observed for all types of heavy metal and at all frequencies greater than $300 \mathrm{kHz}$.

The results also indicate that the loss factor of sand increases with increasing heavy metal content at frequency $500 \mathrm{kHz}$. This trend was observed for all heavy metals and at all frequencies from $100 \mathrm{kHz}$ to $1000 \mathrm{kHz}$. The addition of more heavy metal to the sand converts the sand mixture to high conducting material. This will allow the sand polluted with higher level of heavy metal to loss the AC energy by increasing the pass of the AC current through polluted sand.

The results also indicate that heavy metals possess high density and high electrical resistivity as indicated in Table 3 and have the high dielectric constant and low loss factor. If the density of the heavy metal decreased and its electrical resistivity decreased, the dielectric constant of sand polluted with this metal increased and the loss factor decreased. At the same pollution level, $\mathrm{Pb}$ has the highest dielectric constant and lowest loss factor because $\mathrm{Pb}$ has high density $\left(11.34 \mathrm{~g} / \mathrm{cm}^{3}\right)$ and high resistivity $(208 \mathrm{n} \Omega \mathrm{m})$ as presented in Table 3. Similarly, using the data in Table 3 , $\mathrm{Zn}$ possess the lowest resistivity $(59 \mathrm{n} \Omega \mathrm{m})$ and low density $\left(7.14 \mathrm{~g} / \mathrm{cm}^{3}\right)$; therefore, $\mathrm{Zn}$ has the lowest dielectric and highest loss factor at the same pollution level compared to other heavy metals. 


\section{Conclusions}

The development of fast and effective methods for detecting and treating pollution in soil is of great importance in the scientific community, as it covers a multidisciplinary field of work, due to the great impact of pollution on ecosystems and human health; in particular, heavy metals present in many industrial areas pollute the soil significantly. Therefore, this study proposed a new device called dielectric capacitive cell to calculate the dielectric constant and loss factor from the measured sand impedances. The pure sand artificially contaminated with four heavy metals and at five pollution levels for each heavy metal. The pollution level ranges from $0 \mathrm{mg} / \mathrm{kg}$ to $30 \mathrm{mg} / \mathrm{kg}$ of sand with and increment of $7.5 \mathrm{mg} /$ $\mathrm{kg}$. The dielectric properties obtained using this device shows that both the dielectric constant and loss factor of clean and contaminated sand decrease with increasing frequency in the frequency range from $100 \mathrm{kHz}$ to $1000 \mathrm{kHz}$. The presence of heavy metal in sand causes a decrease in the dielectric constant and an increase of the loss factor of sand. The heavy metal of higher electrical resistance indicates a high dielectric constant and low loss factor for the same level of pollution compared to other heavy metals. The dielectric constant increases with increasing heavy metal electrical resistivity and decreases with increasing heavy metal content. The loss factor shows that opposite trends were the loss factors that increase with increasing electrical resistance of heavy metal and increase with the increasing pollution level. Linear regression models were developed to relate the dielectric properties of sand with the level of heavy metal pollution. The proposed device is a promising tool, and the results obtained could form a base for further studies to evaluate polluted soil with heavy metals. Because this study uses pure sand artificially contaminated with various level of heavy metals in the lab, further use of this method is subjected to necessary evaluation of other factors affecting dielectric properties of sand such as moisture condition, sand type, and soil type. In addition, investigate the usefulness of the method by testing contaminated soil near industrial areas in the field.

\section{Data Availability}

The data used to support the findings of this study are included within the article. Any other additional information used to support the findings of this study are available from the corresponding author upon request.

\section{Conflicts of Interest}

The authors declare that there are no conflicts of interest.

\section{Acknowledgments}

The authors thank several universities for helping and allowing the researchers to use the lab facilities including King Khalid University, Yarmouk University, and Jadara University.

\section{References}

[1] S. K. Prajapati and N. Meravi, "Heavy metal speciation of soil and Calotropis procera from thermal power plant area," Proc. of the Int. Academy of Ecology and Environ. Sci.vol. 4, no. 2, pp. 68-71, 2014.

[2] M. H. Sayadi and M. R. Rezaei, "Impact of land use on the distribution of toxic metals in surface soils in Birjand city, Iran," Proc. of the Int. Academy of Ecology and Environmental Sciences, vol. 4, no. 1, pp. 18-29, 2014.

[3] A. Pejman, G. Nabi Bidhendi, M. Ardestani, M. Saeedi, and A. Baghvand, "A new index for assessing heavy metals contamination in sediments: a case study," Ecological Indicators, vol. 58, pp. 365-373, 2015.

[4] C. Luo, C. Liu, Y. Wang et al., "Heavy metal contamination in soils and vegetables near an e-waste processing site, south China," Journal of Hazardous Materials, vol. 186, no. 1, pp. 481-490, 2011.

[5] M. J. M. Notten, A. J. P. Oosthoek, J. Rozema, and R. Aerts, "Heavy metal concentrations in a soil-plant-snail food chain along a terrestrial soil pollution gradient," Environmental Pollution, vol. 138, no. 1, pp. 178-190, 2005.

[6] A. Beeby, "The role of Helix aspersa as a major herbivore in the transfer of lead through a polluted ecosystem," The Journal of Applied Ecology, vol. 22, no. 1, pp. 267-275, 1985.

[7] G. Tóth, T. Hermann, G. Szatmári, and L. Pásztor, "Maps of heavy metals in the soils of the European Union and proposed priority areas for detailed assessment," Science of The Total Environment, vol. 565, pp. 1054-1062, 2016.

[8] Z. Li, Z. Ma, T. J. van der Kuijp, Z. Yuan, and L. Huang, "A review of soil heavy metal pollution from mines in China: pollution and health risk assessment," Science of The Total Environment, vol. 468-469, pp. 843-853, 2014.

[9] K. Lei, E. Giubilato, A. Critto, H. Pan, and C. Lin, "Contamination and human health risk of lead in soils around lead/ zinc smelting areas in China," Environmental Science and Pollution Research, vol. 23, no. 13, pp. 13128-13136, 2016.

[10] X. Zhang, T. Zhong, L. Liu, and X. Ouyang, "Impact of soil heavy metal pollution on food safety in China," PloS One, vol. 10, no. 8, Article ID e0135182, 2015.

[11] J. O. Duruibe, M. O. C. Ogwuegbu, and J. N. Egwurugwu, "Heavy metal pollution and human biotoxic effects," International Journal of Physical Sciences, vol. 2, pp. 112-118, 2007.

[12] Y. Li, J. Li, and C. Deng, "Occurrence, characteristics and leakage of polybrominated diphenyl ethers in leachate from municipal solid waste landfills in China," Environmental Pollution, vol. 184, pp. 94-100, 2014.

[13] J. Dong, Q.-w. Yang, L.-n. Sun et al., "Assessing the concentration and potential dietary risk of heavy metals in vegetables at a $\mathrm{Pb} / \mathrm{Zn}$ mine site, China," Environmental Earth Sciences, vol. 64, no. 5, pp. 1317-1321, 2011.

[14] G. Nabulo, S. D. Young, and C. R. Black, "Assessing risk to human health from tropical leafy vegetables grown on contaminated urban soils," Science of The Total Environment, vol. 408, no. 22, pp. 5338-5351, 2010.

[15] Q. R. Wang, "Instances of soil and crop heavy metal contamination in China," Soil Sediment Contam, vol. 10, pp. 497-510, 2001.

[16] H. Al-Mattarneh, "Determination of chloride content in concrete using near- and far-field microwave non-destructive methods," Corrosion Science, vol. 105, pp. 133-140, 2016.

[17] M. Jamil, M. K. Hassan, H. M. A. Al-Mattarneh, and M. F. M. Zain, "Concrete dielectric properties investigation 
using microwave nondestructive techniques," Materials and Structures, vol. 46, no. 1-2, pp. 77-87, 2013.

[18] H. M. A. Al-Mattarneh, D. K. Ghodgaonkar, and W. M. B. W. A. Majid, "Microwave sensing of moisture content in concrete using open-ended rectangular waveguide," Subsurface Sensing Technologies and Applications, vol. 2, no. 4, pp. 377-390, 2001.

[19] M. W. Smith and A. R. Tice, "Measurement of the unfrozen water content of soils: a comparison of NMR and TDR methods," in Proceedings of the Fifth International Conference on Permafrost, pp. 473-477, Trondheim, Norway, August 1988.

[20] C. H. Roth, M. A. Malicki, and R. Plagge, "Empirical evaluation of the relationship between soil dielectric constant and volumetric water content as the basis for calibrating soil moisture measurements by TDR," Journal of Soil Science, vol. 43, no. 1, pp. 1-13, 1992.

[21] G. C. Topp, M. Yanuka, W. D. Zebchuk, and S. Zegelin, "Determination of electrical conductivity using time domain reflectometry: soil and water experiments in coaxial lines," Water Resources Research, vol. 24, no. 7, pp. 945-952, 1988.

[22] H. Al-Mattarneh, "Enhancement of parallel plate sensor for electromagnetic characterization of material," European Journal of Scientific Research, vol. 120, no. 3, pp. 348-359, 2014.

[23] M. Dahim, R. Ismail, R. Ismail, H. Al-Mattarneh, and R. Hatamleh, "Determination of leachate pollution content in soil using in-situ dielectric measurement," Advanced Materials Letters, vol. 10, no. 4, pp. 298-301, 2019.

[24] H. Liu, H. Yang, and F. Yi, "Experimental study of the complex resistivity and dielectric constant of chrome-contaminated soil," Journal of Applied Geophysics, vol. 131, pp. 109-116, 2016.

[25] J. H. Lee, M. H. Oh, J. Park, S. H. Lee, and K. H. Ahn, "Dielectric dispersion characteristics of sand contaminated by heavy metal, landfill leachate and BTEX (02-104B)," Journal of Hazardous Materials, vol. 105, no. 1-3, pp. 83-102, 2003.

[26] D. Chenaf and N. Amara, "Time domain reflectometry for the characterization of diesel contaminated soil," in Proceedings of the Int. Symp. And Workshop on Time Domain Reflectometry for Innovative Geotechnical Application, TDR, Evanston, IL, USA, September 2001.

[27] V. Saltas, F. Vallianatos, P. Soupios, J. P. Makris, and D. Triantis, "Dielectric and conductivity measurements as proxy method to monitor contamination in sandstone," Journal of Hazardous Materials, vol. 142, no. 1-2, pp. 520-525, 2007.

[28] V. Saltas, N. Lydakis-Simantiris, P. Soupios, and F. Vallianatos, "Complex dielectric permittivity and electrical conductivity measurements as a diagnostic tool for the detection of heavy metals adsorbed in bentonite samples," in Proceedings of the 3rd International Conference on Industrial and Hazardous Waste Management (CRETE2012), pp. 1-8, Crete, Greece, September 2012.

[29] H. Al-Mattarneh and M. Dahim, "Determination of water quality parameters using microwave nondestructive method," International Journal of Engineering \& Technology, vol. 7, no. 3, pp. 173-176, 2018.

[30] M. Dahim, H. Al-Mattarneh, and R. Ismail, "Simple capacitor dielectric sensors for determination of water content in transformer oil," International Journal of Engineering \& Technology, vol. 7, no. 3, pp. 157-160, 2018.

[31] H. Al-Mattarneh and A. Alwadie, "Development of low frequency dielectric cell for water quality application," Procedia Engineering, vol. 148, pp. 687-693, 2016.
[32] A. Waseem, J. Arshad, F. Iqbal, A. Sajjad, Z. Mehmood, and G. Murtaza, "Pollution status of Pakistan: a retrospective review on heavy metal contamination of water, soil, and vegetables," BioMed Research International, vol. 2014, pp. 129, 2014.

[33] USEPA, Risk-based Concentration Table, United State Environmental Protection Agency, Washington, DC, USA, 2000.

[34] W. F. Brinton, Compost Quality Standards and Guidelines, Woods End Research Laboratory Inc., New York, NY, USA, 2000.

[35] H. Al-Mattarneh, "Surface electromagnetic sensor for evaluation of construction material," European Journal of Scientific Research, vol. 120, no. 3, pp. 360-369, 2014.

[36] L. Rattan and K. S. Manoj, "Basic definition and concepts: soil components and phases," Principles of Soil Physics, vol. 12701, p. 16, 2004. 